\title{
Venous thromboembolism in 13 Indonesian patients undergoing major orthopedic surgery
}

\author{
Karmel L. Tambunan, ${ }^{1}$ Errol U. Hutagalung, ${ }^{2}$ Lugyanti Sukrisman, ${ }^{1}$ Ifran Saleh, ${ }^{3}$ S. Bambang Gunawan, ${ }^{2}$ Sofyanuddin,${ }^{4}$ \\ Arini Setiawati ${ }^{5}$ \\ ${ }^{1}$ Division of Hematology \& Medical Oncology, Thrombosis Hemostasis Center, Department of Internal Medicine, Cipto \\ Mangunkusumo General Hospital - Faculty of Medicine, University of Indonesia, Jakarta, Indonesia \\ ${ }^{2}$ Division of Orthopedic \& Traumatology, Department of Surgery, Cipto Mangunkusumo General Hospital - Faculty of \\ Medicine, University of Indonesia, Jakarta, Indonesia \\ ${ }^{3}$ Division of Orthopedic \& Traumatology, Department of Surgery, Saint Carolus Hospital, Jakarta, Indonesia \\ ${ }^{4}$ Department of Orthopaedic \& Traumatology, Fatmawati General Hospital, Jakarta, Indonesia \\ ${ }^{5}$ Department of Pharmacology and Therapeutics - Faculty of Medicine, University of Indonesia, Jakarta, Indonesia
}

\begin{abstract}
Abstrak
Tujuan Untuk mengetahui kejadian VTE pada pasien Indonesia yang menjalani bedah ortopedi mayor dan tidak menerima tromboprofilaksis.

Metode Uji klinik terbuka pada pasien Indonesia yang menjalani bedah ortopedi mayor, dilakukan di 3 senter di Jakarta. Venografi bilateral dilakukan antara 5 dan 8 hari pasca bedah untuk menemukan VTE yang asimptomatik dan memastikan VTE yang simptomatik. Pasien dievaluasi hingga 1 bulan pasca bedah.

Hasil Telah diteliti 17 pasien dengan median usia 69 tahun dan 76,5\% di antaranya perempuan. Enam belas dari 17 pasien (94,1\%) menjalani bedah fraktur panggul. Median waktu antara fraktur dengan tindakan adalah 23 hari (antara 2 sampai 197 hari), median lamanya tindakan bedah 90 menit (antara 60 sampai 255 menit), dan median lamanya imobilisasi 3 hari (antara 1 sampai 44 hari). Tiga belas dari 17 pasien menjalani venografi kontras untuk mendeteksi VTE yang asimtomatik. VTE ditemukan pada 9 dari 13 pasien (69,2\%) saat akan keluar dari rumah sakit (RS). VTE yang simtomatik ditemukan pada 3 pasien (23,1\%), semuanya dengan tanda-tanda klinis DVT dan tidak seorangpun dengan tanda klinis embolisme paru (PE). Pasien tersebut diobati dengan heparin berat molekul rendah, dilanjutkan dengan antikoagulan oral warfarin. Tidak ada kematian mendadak sampai pasien keluar dari RS. Tidak ada kasus VTE simtomatik baru sejak keluar dari RS sampai 1 bulan kemudian. Tidak ditemukan kematian mendadak, komplikasi pendarahan, ataupun perawatan ulang di RS dalam studi ini.
\end{abstract}

Kesimpulan Insidens VTE asimtomatik sebesar 69,2\% dan simtomatik 23,1\% setelah bedah ortopedi mayor tanpa tromboprofilaksis. Studi yang lebih besar dibutuhkan untuk memastikan insidens yang benar, dan yang lebih penting, untuk menggunakan tromboprofilaksis pada pasien-pasien ini. (Med J Indones 2009; 18: 249-56)

\begin{abstract}
Aim To estimate the incidence of VTE in Indonesian patients undergoing major orthopedic surgery and not receiving thromboprophylaxis.

Methods This was an open clinical study of consecutive Indonesian patients undergoing major orthopedic surgery, conducted in 3 centers in Jakarta. Bilateral venography was performed between days 5 and 8 after surgery to detect the asymptomatic and to confirm the symptomatic VTE. These patients were followed up to one month after surgery.

Results A total of 17 eligible patients were studied, which a median age of 69 years and $76.5 \%$ were females. Sixteen out of the 17 patients $(94.1 \%$ ) underwent hip fracture surgery (HFS). The median time from injury to surgery was 23 days (range 2 to 197 days), the median duration of surgery was 90 minutes (range 60 to 255 minutes), and the median duration of immobilization was 3 days (range 1 to 44 days). Thirteen out of the 17 patients were willing to undergo contrast venography. A symptomatic VTE was found in 9 patients $(69.2 \%)$ at hospital discharge. Symptomatic VTE was found in 3 patients (23.1\%), all corresponding to clinical signs of DVT and none with clinical sign of PE. These patients were treated initially with a low molecular weight heparin, followed by warfarin. Sudden death did not occur up to hospital discharge. From hospital discharge until 1-month follow-up, there were no additional cases of symptomatic VTE. No sudden death, bleeding complication, nor re-hospitalization was found in the present study.

Conclusion The incidence of asymptomatic (69.2\%) and symptomatic (23.1\%) VTE after major orthopedic surgery without thromboprophylaxis in Indonesian patients (SMART and AIDA), and still higher than the results of the Western studies. A larger study is required to establish the true incidence, and more importantly, that the use of thromboprophylaxis in these patients is warranted. (Med J Indones 2009; 18: 249-56)
\end{abstract}

Key words: venous thromboembolism (VTE), orthopedic surgery, Indonesia 
In Asian patients undergoing surgery, the incidence of venous thromboembolism (VTE) is believed to be low relative to Western patients, and the routine use of thromboprophylaxis is controversial. However, in a recent review of published studies in Asian patients undergoing surgery and not receiving thromboprophylaxis ${ }^{1}$, the adjusted incidence of total (asymptomatic and symptomatic) deep vein thrombosis (DVT) was 13\% in general surgery, $16 \%$ after total hip replacement, $50 \%$ after total knee replacement, and 18\% after hip fracture surgery. The adjusted incidence of symptomatic pulmonary embolism (PE) was $1 \%$ in general surgery and $1.4 \%$ after total hip replacement. In autopsy studies, the incidence of fatal PE increasing consistently from $0.2 \%$ to $6.0 \%$ over a period of 30 years in Japan and Hongkong. ${ }^{1}$

A study in Malaysian patients who had orthopedic surgery with no prophylaxis against $\mathrm{DVT}^{2}$ showed that the venographic DVT was $62.5 \%$, it was highest after total knee replacement (76.5\%), less after total hip replacement $(64.3 \%)$, and lowest in the fracture group (50\%). One patient developed symptomatic PE.

The epidemiological study of VTE in Asian patients undergoing major orthopedic surgery without thromboprophylaxis (the SMART Study) ${ }^{3}$ showed that the rate of the composite of symptomatic VTE or sudden death at hospital discharge was $1.2 \%$ after adjudication by an independent committee. The rates of symptomatic VTE, DVT and PE were 1.0\%, 0.9\% and $0.2 \%$, respectively. The rates of the composite outcome were $1.4 \%$ in patients undergoing total knee replacement surgery and $1.0 \%$ in patients operated on for hip fracture or total hip replacement. Sudden death was reported in hip fracture surgery patients $(0.4 \%)$ only. At 1 month's follow-up, the incidence of adjudicated symptomatic VTE or sudden death was $1.5 \%$.

In addition, results of the SMART venography study (a part of the SMART program, conducted in different patients and centers) ${ }^{4}$ showed that in Asian patients undergoing hip or knee surgery and not receiving pharmacological thromboprophylaxis, the rate of the composite of adjudicated asymptomatic or symptomatic VTE or sudden death up to hospital discharge was 36.5\%. The rate of symptomatic VTE (all were symptomatic DVT) was $0.9 \%$. The rate of the composite outcome at the 1-month follow-up was $1.5 \%$.

The above studies suggest that in Asian patients, the incidence of symptomatic VTE after major orthopedic surgery is not low, but comparable to the rates observed in Western countries ${ }^{5,6}$.
The aim of the present study was to estimate the incidence of VTE defined as symptomatic or asymptomatic DVT or PE or sudden death in Indonesian patients undergoing total hip or knee replacement or surgery for hip fracture or acute spinal cord injury or major trauma or pelvis fracture and not receiving thromboprophylaxis. VTE was detected by systematic bilateral venography performed between days 5 and 8 after surgery. The secondary objective was to describe the clinical features of the VTE.

\section{METHODS}

This was an open clinical study of consecutive Indonesian patients undergoing major orthopedic surgeries. It was conducted in 3 centers in Jakarta, Cipto Mangunkusumo General National Hospital, Saint Carolus Hospital, and Fatmawati General Hospital, started in March 2003 and ended in March 2004.

\section{Patients}

Indonesian patients aged at least 40 years, hospitalized for total hip or knee replacement or hip fracture or acute spinal cord injury or major trauma or pelvis fracture, were recruited. Patients having received any thromboprophylaxis treatment within the week preceding inclusion, and those with contraindication to venography, were excluded. Pregnant women and patients refusing informed consent to participate were also excluded.

\section{Study procedures}

The following patient and surgery characteristics were recorded as potential risk factors for symptomatic VTE or sudden death (primary outcome) : age, gender, weight and height, smoking habit, history of cancer or currently active cancer, personal or familial history of VTE, known thrombophilia, peptic ulcer, chronic heart failure, varicose veins, myocardial infraction, arterial hypertension, hormone therapy (estrogen, hormone replacement therapy, or anti-androgen), blood glucose level, D-dimer level, time between injury and surgery, duration of surgery, type of anesthesia (general or regional), surgery sites, duration of immobilization, complications after surgery, concomitant treatments after surgery.

Patients underwent a bilateral ascending contrast venography of the lower extremities using Rabinov \& Paulin technique to detect asymptomatic DVT. If a DVT is clinically suspected before Day 5 , the diagnosis should 
be confirmed by venography within 48 hours. Clinical suspicion of PE should be objectively confirmed by highprobability lung scanning or pulmonary angiography, or at autopsy or, in patients who died suddenly without autopsy and whose clinical history was that of a death by PE, as adjudicated by the physicians.

After hospital discharge, patients were contacted, by mail, telephone or visit in person, 1 month (between day 30 and day 37) after surgery and asked to report any symptoms and signs of VTE, bleeding, rehospitalization, or survival status (dead/alive). In patients presenting with VTE (symptomatic DVT/PE or objectively by venography), the decision of treatment was left to the investigator's discretion.

The following bleeding complications up to hospital discharge were recorded : fatal bleeding, bleeding leading to re-operation, bleeding requiring transfusion of at least 2 units of packed red blood cells or whole blood, bleeding leading to a hemoglobin decrease $>20$ $\mathrm{g} / \mathrm{L}$ compared with baseline value, bleeding in a critical organ (retroperitoneal, intraocular or intracranial).

This study was conducted according to the standards of good clinical practice (the ICH E6 Guideline for Good Clinical Practice), in agreement with the Declaration of Helsinki and with local regulations. The protocol was approved by the Ethics Committee of the Medical Faculty, University of Indonesia, Jakarta, and written informed consent was obtained from each subject before inclusion into the study.

\section{Study outcomes}

The primary study outcome was the incidence of documented VTE (defined as asymptomatic or symptomatic DVT or PE) and sudden death at hospital discharge and at 1-month follow-up.

The secondary study outcome was the description of the clinical features of the VTE.

\section{Data Analysis}

The primary analysis was the incidence of documented VTE at hospital discharge and at one-month followup (day 30-day 37) in patients undergoing orthopedic surgery and not receiving pharmacological thromboprophylaxis. The data were analyzed according to descriptive statistics : number of cases, mean, median, standard deviation and range for quantitative data, and number of cases and percentages for qualitative data. The secondary analysis was the description of patients clinical features related to VTE.

\section{RESULTS}

\section{Patient characteristics}

Seventeen eligible patients were recruited. Female patients were three times more prevalent than males. The median age of the patients was 69 years (range 42-83 years). Among risk factors for VTE, only 1 patient (5.9\%) had familial history of VTE, and no one had personal history of VTE or known thrombophilia. Cancer and varicose veins were not found in any of the 17 patients, while gastrointestinal disturbances were found in almost half of the patients (47.1\%), and 3 patients (17.6\%) had myocardial infarction. Stroke, chronic heart failure and hypertension were also not found in these patients, but diabetes and smoking were found in 5 patients $(29.4 \%)$ and 1 patient (5.9\%), respectively. Abnormal hematology was noted in 2 patients $(11.8 \%)$ with anemia, 6 patients $(35.3 \%)$ with leucocytosis, and 5 patients $(29.4 \%)$ with high neutrophil count. Bleeding time $>3$ minutes was found in 1 patient $(5.9 \%)$ and D-dimer level $>400 \mathrm{mg} /$ $\mathrm{mL}$ in 9 patients $(52.9 \%)$ (Table 1$)$.

\section{Surgical characteristics}

Almost all patients (94.1\%) underwent surgery for hip fracture (Table 2). The median interval from injury to surgery was 23 days (range 2-197 days) and the median duration of surgery was 90 minutes (range 60255 minutes). Surgery was conducted mainly under regional (spinal) anesthesia ( $94.1 \%$ of patients). The type of surgery was mainly hemiarthroplasty (in 64.7\% of patients), followed by plate screw (in $23.5 \%$ of patients). The median duration of immobilization was 3 days (range 1-44 days).

\section{Concomitant treatments after surgery}

Postoperatively up to hospital discharge, no patient applied graduated compression device, while physiotherapy was provided to 15 patients $(88.2 \%)$. Three patients with symptomatic VTE(see Table 3) were treated initially with a low molecular weight heparin, followed by warfarin (an oral anticoagulant) (Table 2). Only 1 patient was given antiplatelet (aspirin). Fourteen patients (82.4\%) received nonsteroid anti-inflammatory drugs, and antibiotics were also given to 14 patients $(82.4 \%)$ (Table 2$)$. 


\section{VTE up to hospital discharge}

From a total of 17 eligible patients, bilateral venography was performed in 13 patients $(76.5 \%)$, all of them underwent surgery for hip fracture. Four patients refused and withdrew their consent. In 11 patients, venography was performed between days 5 and 8 after surgery (as planned), whereas in 2 patients it was performed after day 8 ( 1 on day 9 and 1 on day 10), with day 7 as the median (Table 3).

The rate of venographic VTE (asymptomatic or symptomatic DVT or PE) and sudden death (the primary outcome) up to hospital discharge was $69.2 \%$ ( 9 patients among 13 patients who underwent venography) (Table 3). Proximal DVT was present in 3 patients (23.1\%), 2 patients with asymptomatic and 1 patient with symptomatic DVT. The rate of symptomatic VTE, all corresponding to clinical signs of DVT and no clinical sign of PE, was $23.1 \%$ ( 3 out of 13 patients). Among 6 patients with asymptomatic DVT, distal DVT occurred most frequently (in 5 patients). Sudden death did not occur and also there was no bleeding complication until hospital discharge in the present study.

Table 1. Patient characteristics and hematology before surgery

\begin{tabular}{|c|c|c|}
\hline \multirow{2}{*}{$\begin{array}{l}\text { Number of patients }(\%) \\
\text { Gender : Male / Female n (\%) }\end{array}$} & \multirow{2}{*}{\multicolumn{2}{|c|}{$\begin{array}{l}17 \quad(100) \\
4 / 13(23.5 / 76.5)\end{array}$}} \\
\hline & & \\
\hline : Mean (SD) & 67.5 & $(11.25)$ \\
\hline Median (range) & 69 & $(42-83)$ \\
\hline Weight (kg) : & 58.4 & $(11.05)$ \\
\hline Median (range) & 60 & $(41-75)$ \\
\hline \multirow{2}{*}{$\begin{aligned} \text { Height }(\mathrm{cm}): & \text { Mean }(\mathrm{SD}) \\
& \text { Median (range) }\end{aligned}$} & \multicolumn{2}{|c|}{$158.8(6.40)$} \\
\hline & 159 & $(150-168)$ \\
\hline \multicolumn{3}{|l|}{ Risk factors for VTE : } \\
\hline Familial history of VTE, n (\%) & 1 & $(5.9)$ \\
\hline Personal history of VTE, n (\%) & 0 & $(0)$ \\
\hline Known thrombophilia, n (\%) & 0 & $(0)$ \\
\hline Cancer, n (\%) & 0 & $(0)$ \\
\hline Varicose veins, n (\%) & 0 & $(0)$ \\
\hline Gastrointestinal disturbances, n (\%) & 8 & $(47.1)$ \\
\hline Myocardial infarction, n (\%) & 3 & $(17.6)$ \\
\hline Stroke, n (\%) & 0 & $(0)$ \\
\hline Chronic heart failure, n (\%) & 0 & $(0)$ \\
\hline Hypertension, $\mathrm{n}(\%)$ & 0 & $(0)$ \\
\hline Diabetes, n (\%) & 5 & $(29.4)$ \\
\hline Smoking, n (\%) & 1 & $(5.9)$ \\
\hline \multicolumn{3}{|l|}{ Hematology before surgery : } \\
\hline Hemoglobin $<10 \mathrm{~g} / \mathrm{dL}, \mathrm{n}(\%)$ & 2 & $(11.8)$ \\
\hline White blood cells $>10.10^{3} / \mu \mathrm{L}, \mathrm{n}(\%)$ & 6 & $(35.3)$ \\
\hline Neutrophil count $>8.10^{3} / \mu \mathrm{L}, \mathrm{n}(\%)$ & 5 & $(29.4)$ \\
\hline Bleeding time $>3 \min , \mathrm{n}(\%)$ & 1 & $(5.9)$ \\
\hline D-dimer level > 400 ng/mL, n (\%) & 9 & $(52.9)$ \\
\hline
\end{tabular}


Table 2. Surgical characteristics and treatments from surgery to hospital discharge

\begin{tabular}{|c|c|c|}
\hline \multirow[t]{2}{*}{ Surgery sites } & : hip fracture, n $(\%)$ & $16(94.1)$ \\
\hline & pelvis fracture, $\mathrm{n}(\%)$ & $1(5.9)$ \\
\hline \multicolumn{2}{|c|}{ Time from injury to surgery (days) : median (range) } & $23(2-197)$ \\
\hline \multicolumn{2}{|c|}{ Duration of surgery (minutes) : median (range) } & $90(60-255)$ \\
\hline \multicolumn{2}{|c|}{ Duration of immobilization (days) : median (range) } & $3(1-44)$ \\
\hline \multicolumn{2}{|c|}{ Type of anesthesia : general, n (\%) } & $1(5.9)$ \\
\hline \multirow{4}{*}{ Type of surgery } & regional (spinal), n (\%) & $16(94.1)$ \\
\hline & plate screw, n (\%) & $4(23.5)$ \\
\hline & hemiarthroplasty, n (\%) & $11(64.7)$ \\
\hline & other, n $(\%)$ & $2(11.8)$ \\
\hline \multicolumn{2}{|c|}{ Graduated compression device, $\mathrm{n}(\%)$} & $0(0)$ \\
\hline \multicolumn{2}{|c|}{ Physiotherapy, n (\%) } & $15(88.2)$ \\
\hline \multirow[t]{3}{*}{ Anticoagulant } & : heparin, $\mathrm{n}(\%)$ & $0(0)$ \\
\hline & low mol. wt. heparin, n (\%) & $3(17.6)$ \\
\hline & oral, $\mathrm{n}(\%)$ & $3(17.6)$ \\
\hline \multirow[t]{2}{*}{ Antiplatelet } & :aspirin, n (\%) & $1(5.9)$ \\
\hline & other, n $(\%)$ & $0(0)$ \\
\hline \multicolumn{2}{|c|}{ Nonsteroid anti-inflammatory agents, $\mathrm{n}(\%)$} & $14(82.4)$ \\
\hline \multicolumn{2}{|c|}{ Antibiotics, n (\%) } & $14(82.4)$ \\
\hline
\end{tabular}

Table 3. Venographic VTE and sudden death up to hospital discharge

\begin{tabular}{lrl}
\hline \multicolumn{1}{c}{ Variables } & $\mathrm{n}$ & $(\%)$ \\
\hline Total patients with venography performed $^{* \dagger}+$ & 13 & $(76.5)$ \\
VTE or sudden death (primary outcome) & 9 & $(69.2)$ \\
Asymptomatic DVT : & 6 & $(46.2)$ \\
Proximal DVT only & 1 & $(7.7)$ \\
Distal DVT only & 4 & $(30.8)$ \\
Proximal and distal DVT & 1 & $(7.7)$ \\
Symptomatic VTE & 3 & $(23.1)$ \\
Symptomatic DVT** & 3 & $(23.1)$ \\
Symptomatic PE & 0 & $(0)$ \\
Sudden death & 0 & $(0)$ \\
\hline
\end{tabular}

* all after hip fracture surgery (HFS)

$\dagger$ Time from surgery to venography (days): median (range) 7 (5 - 10)

** 2 distal DVT and 1 proximal \& distal DVT 


\section{VTE up to 1-month follow-up}

The same 13 patients who discharged from hospital without withdrawal of consent were followed up for a median of 31 days (range 28-36 days) after surgery. All were contacted by visit in person. From hospital discharge until the end of follow-up, no additional symptomatic VTE occurred, and also no sudden death, bleeding complication, nor re-hospitalization was found in the present study.

\section{Clinical features of the VTE}

In the present study, the symptomatic VTE occurred in 3 patients, who experienced symptomatic DVT only, with no symptomatic PE. The symptomatic DVT manifested itself as local clinical signs, one patient with distal DVT (at the right anterior and posterior tibial veins and left posterior tibial vein) experienced edema. The second patient with proximal DVT (at the right femoral vein) and distal DVT (at the right peroneal vein and the right bifurcation of anterior and posterior tibial veins) had edema, pain and tenderness. The third patient with distal DVT (at the right anterior and posterior tibial veins and peroneal vein) had edema.

\section{DISCUSSION}

Venous thromboembolism (VTE) is a serious complication most commonly occur after surgery, major trauma or immobilization ${ }^{5}$. VTE includes deep venous thrombosis (DVT) and pulmonary embolism (PE), approximately one third of patients with VTE have a PE, whereas two thirds have DVT alone ${ }^{7}$. In Western countries, the absolute risk of DVT in hospitalized patients not receiving thromboprophylaxis ranges from 10 to $80 \%$, the lowest in medical patients (10-20\%), and the highest in spinal cord injury (60-80\%), major trauma $(40-80 \%)$ and orthopedic surgery $(40-60 \%)^{5}$. Therefore, thromboprophylaxis is warranted, because DVT and $\mathrm{PE}$ are mostly asymptomatic and it is difficult to predict which patients will develop symptomatic DVT or PE which cause serious morbidity and mortality, while thromboprophylaxis is highly efficacious at preventing asymptomatic and symptomatic DVT and fatal $\mathrm{PE}^{5,6}$.

The present study was to verify the results of the previous Asian studies about the incidence of VTE in patients undergoing orthopedic surgery without thromboprophylaxis in Indonesian patients. The planned sample size for this study was 62 patients examined for DVT using venography, but only 17 eligible patients were enrolled and only 13 patients (76.5\%) were willing to undergo venography. Bilateral contrast venography using Rabinov \& Paulin technique was used to detect asymptomatic DVT in this study. Although invasive, venography is considered the gold standard diagnostic technique for this purpose, because it is both sensitive and specific. ${ }^{8}$ We found in the present study, the rate of venographic VTE (asymptomatic or symptomatic DVT or PE) and sudden death (the primary outcome) was $69.2 \%$ and the rate of proximal DVT was $23.1 \%$ at hospital discharge, and these rates were from patients undergoing hip fracture surgery (HFS). Compared to other studies conducted in Asia, these rates were too high, considering our patients had a low-risk profile for VTE (see Table 1). Also, almost all of the patients $(94.1 \%)$ received regional anesthesia, which reportedly associated with less DVT after HFS ${ }^{5}$. From the exhaustive literature search for published studies on VTE in Asia $^{1}$, the incidence of total venographic DVT in 141 HFS patients ranged from 6.9 to $50.0 \%$, and that of venographic proximal DVT was 2.8 to $3.4 \%$. In the Malaysian study ${ }^{2}$, the incidence of venographic DVT in 88 patients with orthopedic surgery was $62.5 \%$ and that in 40 patients with proximal femoral fracture was 50\%. In the SMART (Surgical Multinational Asian Registry in Thrombosis) venography study ${ }^{4}$, there was no HFS patients, while the rate of venographic VTE (asymptomatic or symptomatic DVT) in 326 patients with hip and knee replacement surgery was $36.5 \%$ and that of proximal DVT was $9.8 \%$ at hospital discharge. In the AIDA (Assessment of the Incidence of Deepvein thrombosis in Asia) ${ }^{9}$, the incidence of venographic DVT in 69 HFS patients was $42.0 \%$, and that of proximal DVT was $7.2 \%$. By-country analysis in AIDA study showed that the highest DVT rate occurred in Indonesia (78.6\%), but it was not mentioned from how many patients. Considering the Malay ethnic consisted of only 12 patients in AIDA study, we assumed that the number of Indonesian patients in that study was small, as it was in the present study. In Western patients, the rate of venographic DVT after HFS ranged form 46 to $60 \%$, and that of proximal DVT was 23 to $30 \%$. The proximal DVT is more important than the distal DVT because proximal DVT is considered to have a higher risk of embolizing than distal DVT. ${ }^{10}$ The high risk of VTE in the present HFS patients may be due to the advanced age (median 69 years) and the predominant women $(76.5 \%)$ in this study (see Table 1). The same was true in Western studies ${ }^{5}$ and in AIDA study ${ }^{9}$. Delayed surgery also increased the risk of VTE in HFS patients. The incidence of preoperative DVT as 
shown by venography was $62 \%$ for all DVT and $14 \%$ for proximal DVT when the delay was 48 hours or more. $^{5,6}$

To confirm clinical suspicion of PE, a high-probability lung scan has the positive predictive value of $93 \%$, while pulmonary angiography is considered the gold standard diagnostic technique for $\mathrm{PE}^{8}$. In the present study, the rate of symptomatic VTE was $25 \%$, all corresponding to clinical signs of DVT and no clinical sign of PE. In the review of all previously published studies on VTE in Asia ${ }^{1}$, the rate of symptomatic DVT in 53 HFS patients was $28.3 \%$ and no symptomatic PE was found among all of the HFS patients. In the Malaysian study $^{2}$, the rate of symptomatic DVT in 55 patients with venographic DVT was $34.5 \%$, and 1 patient developed clinical features of PE. In the SMART study ${ }^{3}$, the rate of symptomatic DVT in 1068 HFS patients was $0.5 \%$ and that of symptomatic PE was $0.3 \%$ up to hospital discharge. In SMART venography study ${ }^{4}$, there was no HFS patients, while the rate of symptomatic DVT in 326 patients with hip and knee replacement surgery was $0.9 \%$, and no symptomatic PE was found up to hospital discharge. In AIDA study ${ }^{9}$, the rate of symptomatic DVT in 374 patients with a venogram was $12.6 \%$, while a perfusion-lung-scan confirmed PE in 2 patients $(0.5 \%)$. In Western patients, the rate of total symptomatic PE after HFS ranged from 3 to $11 \%$, and the fatal PE was in the range of 2.5 to $7.5 \%$ within 3 months after HFS, a range higher than that seen after hip or knee arthroplasty. ${ }^{5,6}$ The 90-day risk of overall death was $13 \%{ }^{6}$. Western patients after HFS are indeed at very high risk of VTE. Symptomatic VTE and fatal PE after HFS in these patients can be prevented with thromboprophylaxis. ${ }^{5,6}$

In the present study the rate of asymptomatic DVT was twice the rate of symptomatic VTE. This silent nature of VTE found in this study was consistent with the other Asian studies (the review of previous Asian studies, SMART study and AIDA study) $)^{1,4,9}$ as well as with Western studies. ${ }^{5}$

In the present study, there was no additional symptomatic VTE or death between hospital discharge and 1-month follow-up. The same was true in AIDA study ${ }^{9}$ until 3-month follow-up, while in SMART study ${ }^{3}$, the additional number of cases was small, from $1.2 \%$ of patients at hospital discharge to $1.5 \%$ of patients at 1-month follow-up. In SMART venography study ${ }^{4}$, the additional number of cases was also small, from 3 patients at hospital discharge to 5 patients at 1-month follow-up. In Western studies, there were higher additional symptomatic VTE cases after hospital discharge, ranged between $2.7 \%$ and 4.3\%. ${ }^{5}$ Discrepancy between the Asian studies with the Western studies in this regard was primarily due to a lack of awareness of clinical symptoms of DVT, especially because non-specific symptoms in the legs are common after major hip or knee surgery.

In conclusion, the very high incidence of asymptomatic and symptomatic VTE after major orthopedic surgery without thromboprophylaxis in Indonesian patients found in the present study was higher than the results of the large Asian studies (SMART and AIDA), and still higher than the results of the Western studies. This may due to chance because of the small sample size of the study. Nevertheless, these results suggest that the incidence of VTE in Indonesian patients undergoing major orthopedic surgery is not low, and a larger study in Indonesian patients is required to establish the true incidence, and more importantly, that the use of thromboprophylaxis in these patients is warranted.

\section{REFERENCES}

1. Leizorovicz A, Turpie AGG, Cohen AT, Dhillon KS, Angchaisuksiri P, Wang C-J, for the SMART Study Group. Epidemiology of post-operative venous thromboembolism in Asian Countries. Int J Angiol. 2004; 13 : 101-8.

2. Dhillon KS, Askander A, Doraisamy S. Postoperative deep-vein thrombosis in Asian patients is not a rarity: a prospective study of 88 patients with no prophylaxis. J Bone Joint Surg. 1996; 78-B (3): 427-30.

3. Leizorovicz A, Turpie AGG, Cohen AT, Wong L, Yoo MC, Dans A, for the SMART Study Group. Epidemiology of venous thromboembolism in Asian patients undergoing major orthopedic surgery without thromboprophylaxis. The SMART Study. J Thromb Haemost. 2005; $3: 28$ - 34 .

4. Leizorovicz A on behalf of the SMART Venography Study Steering Committee. Epidemiology of post-operative venous thromboembolism in Asian patients. Results of the SMART venography study. Hematologica. 2007; 92: 1194 $-200$.

5. Geerts WH, Pineo GF, Heit JA, Bergqvist D, Lassen MR, Colwell CW, et al. Prevention of venous thromboembolism : the seventh ACCP conference on antithrombotic and thrombolytic therapy. Chest. 2004;126:338 - 400.

6. Nicolaides AN, Fareed J, Kakkar AK, Breddin HK, Goldhaber SZ, Hull R, et al. Prevention and treatment of venous thromboembolism. International Concensus Statement. Guidelines according to scientific evidence. Int Angiol. 2006; 25(2) : $101-61$.

7. White RH. The epidemiology of venous thromboembolism. Circulation. 2003; 107 : I-4 - I-8 
8. American Thoracic Society: Medical Section of the American Lung Association. The diagnostic approach to acute venous thromboembolism. Clinical Practice Guideline. Am J Respir Crit Care Med. 1999; 160 : 1043 - 66

9. Piovella F, Wang C-J, Lu H, Lee K, Lee LH, Lee WC, et $\mathrm{al}$, for the AIDA Investigators. Deep-vein thrombosis rates after major orthopedic surgery in Asia. An epidemiological study based on postoperative screening with centrally adjudicated bilateral venography. J Thromb Haemost. $2005 ; 3: 2664-70$.

10. Kakkar VV, Howe CT, Flanc C, Clarke MB. Natural history of postoperative deep-vein thrombosis. Lancet. 1969; 2 : $230-2$. 